\title{
EFFECT OF PULSE LASER ENERGY DENSITY ON TiC CLADDING OF ALUMINIUM SUBSTRATE
}

\author{
Janez Sušnik, Janez Grum, Roman Šturm
}

Original scientific paper In this work, TiC cladded layer has been produced by laser scanning over the preplaced TiC powder on aluminium substrate, using a pulse Nd:YAG laser. Depending on the effective energy density at the specimen surface, $\mathrm{TiC}$ was deposited or partially dispersed into the melted aluminium at the specimen surface. Microstructure was evaluated using optical microscopy and SEM/EDS analysis. Depth of laser cladded layer and microhardness measurements have been deliberated at the cross-section of laser cladded specimens. Effect of pulse laser energy density on cladding layer depth, microhardness, surface roughness and waviness has been studied. From the experimental analysis it is revealed that effective energy density has a significant effect on the TiC cladded surface roughness and waviness, but very little on microhardness of the cladded layer.

Keywords: aluminium; cladding; energy density; pulse laser; TiC

Učinak gustoće pulzirajuće energije lasera na oblaganje aluminijske podloge TiC-om

Izvorni znanstveni članak

U ovom je radu sloj obložen TiC-om proizveden skeniranjem laserom preko prethodno položenog praha TiC-a na aluminijsku podlogu pomoću pulzirajućeg Nd:YAG lasera. Ovisno o efektivnoj gustoći energije na površini uzorka, TiC je položen ili djelomično raspršen u rastaljeni aluminij na površini uzorka. Mikrostruktura je određena pomoću optičkog mikroskopa i SEM/EDS analize. Dubina obloženog sloja i mjerenja mikrotvrdoće određena su na poprečnom presjeku uzoraka oblaganih pomoću lasera. Analizirao se učinak gustoće pulzirajuće energije lasera na dubinu oblaganja sloja, mikrotvrdoću, površinsku hrapavost i valovitost. Eksperimentalna analiza je pokazala da efektivna gustoća energije značajno utječe na hrapavost 1 valovitost površine obložene TiC-om, ali vrlo malo na mikrotvrdoću obloženog sloja.

Ključne riječi: aluminij; gustoća energije; oblaganje; pulzirajući laser; TiC

\section{Introduction}

The role of laser technology has intensively increased in surface engineering. In practice, various laser melting procedures can be effectively used in creation of functional parts. The most important laser processes are as follows: laser-heat treatment, laser remelting, laser cladding and laser alloying [1].

Laser-assisted coating is a surface modification process characterized by high processing speed, controlled precision, and by its applicability. In the literature, it is found that for most of the cases a coating of hard ceramic particles forms a protective layer, which significantly improves the strength, stiffness and wear resistance of the bulk components $[2 \div 6]$. Laser cladding is a process which provides enough engineering thickness and excellent bonding with the substrate. Due to the minimized heat conduction into substrate, laser cladding technique shows extraordinarily distinct advantages such as negligible distortion, low dilution, high hardness, narrow heat affected zone (HAZ) and reduced cracking susceptibility. Laser cladding with pre-placed powder is a simple and versatile method provided the powder can be made to remain in place until melted. For this reason some form of binder is usually used and the laser beam is scanned over the powder bed paste $[1,3,5,6]$. The general theory for cladding of pre-placed powder can be based on the work of Powell et al. [7]. The absorption of laser power is dependent on the materials and their surface condition of the preplaced layer. According to Deng et al. [8] the absorption of the preplaced layer is always assumed as a constant which should be in the range from 0,2 to 0,3 . Even though the TiC melting temperature is higher than the boiling point of aluminium, this can be possible as the absorption coefficient of $\mathrm{TiC}$ at the laser wavelength is three times than the one of aluminium, as described by Lietchi et al. [9]. Consequently, the TiC particles can be melted during the injection, while the $\mathrm{Al}$ powder is not boiled, leading to the $\mathrm{Al}_{4} \mathrm{C}_{3}$ precipitation in the molten pool.

Lei et al. [10] have proposed a new three-dimensional model to simulate the high power laser clad $\mathrm{TiC}$ composite coatings using commercial finite element analysis software. Jianing et al. [11] discussed the microstructure, micro-hardness and phase constitutes in the $\mathrm{Al}+\mathrm{TiC}$ laser cladding layer deposited on $\mathrm{Ti}-6 \mathrm{Al}-4 \mathrm{~V}$ alloy by adding different TiC contents. Although there was a great temperature gradient between the laser cladding layer and substrate, there was a metallurgical bond between the laser cladding layer and Ti-6Al-4V substrate. When the mass percent of $\mathrm{TiC}$ was $40 \%$, the micro-hardness of cladding layer may be up to 3 times more than that of the substrate. Kadolkar et al. [12] have found for $\mathrm{TiC}$ coatings and for the range of processing parameters employed, the residual macro-stresses were compressive in nature. The residual micro-stresses in the Al matrix of the coating were tensile, whereas those in the TiC particles were compressive. The most important industrial use of $\mathrm{TiC}$ is for wear-resistant applications. Most of researchers study the effect of laser scanning speed of continuous lasers on size and morphology of cladded layer. Ochonogor et al. [13] found that grains of titanium carbide were uniformly distributed throughout the metal matrix which contributed to excellent level of resistance to wear and increase in the hardness value. And they have not found any correlation between hardness and abrasive wear due to differences in composition. Duraiselvam et al. [14] discussed the influence of hardness of $\mathrm{TiC}$ laser cladded layers on erosion resistance. The co-existence of cavitation erosion resistant 
intermetallics in a carbide reinforced matrix was responsible for the improved erosion resistance and the failure mode of the eroded area was characterized as brittle fracture. Dubourg et al. [15] described laser cladding of MMC coatings on aluminium substrate. The microstructure of the coatings was homogeneous and free of pores or cracks. Carbides were uniformly distributed throughout the coating cross-section. Ravnikar et al. $[5,6]$ obtained a coating with $\mathrm{TiC}$ and $\mathrm{TiB}_{2}$ particles of various shapes and sizes embedded in an Al matrix. Thermal effects of the coating process and rapid cooling contributed to the occurrence of forced dissolution with reduced microhardness. Even though the average microhardness of the coating is about $40 \%$ higher than the substrate hardness. The coating shows exceptional wear resistance.

Melting ratio is known as a suitable factor to illustrate the effects of process parameters on the clad profile in order to provide a proper process design. However, the definition of melting ratio based on continuous irradiation of energy does not accommodate for pulse parameters. It is established that energy density and interaction time are two essential parameters in laser cladding process which affect the clad profile the most [16]. Farnia et al. [17] showed that the effects of pulse duration and overlapping factor are different at low and high values, and therefore it is difficult to find optimum values for pulse duration and overlapping factor to achieve maximum efficiency in preplaced pulsed laser cladding process.

\section{Materials and methods}

\subsection{Selection of base aluminium alloy and cladding powder}

The chemical composition of the selected hypoeutectic aluminium AlSi12 CuNiMg alloy (ISO) is: $12 \mathrm{Si}$; $0,93 \mathrm{Cu} ; 0,9 \mathrm{Ni} ; 1,04 \mathrm{Mg}$; in wt. \%, Al balance. The aluminium alloy was used in as-delivered state, i.e. ascast state with additional homogenization heat treatment. Heat treatment contains hardening to maximum strength by solution heat treatment at $520 \div 530{ }^{\circ} \mathrm{C}$ for $5 \div 10$ hours, followed by quenching and artificial ageing at 150 $\div 175^{\circ} \mathrm{C}$ for $5 \div 15$ hours.

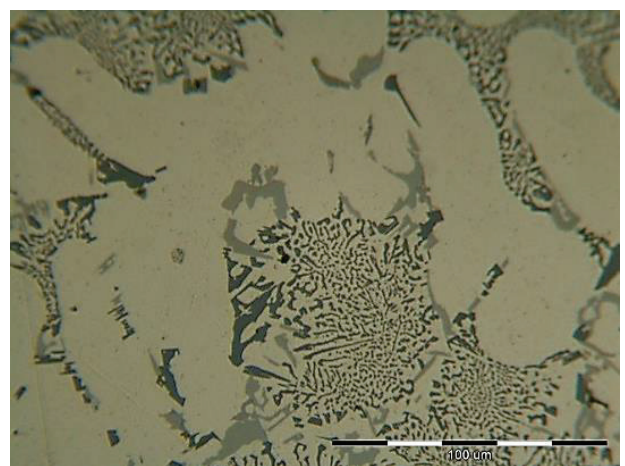

Figure1 Microstructure of as-cast AlSi12CuNiMg alloy, etched

The selected alloy AlSi12CuNiMg is hypo-eutectic and containing inter-dendritic network of eutectic silicon with different intermetallic compounds which improve alloy micro-hardness. Intermetallic compounds are $\mathrm{Mg}_{2} \mathrm{Si}$ (black script), $\mathrm{Al}_{6} \mathrm{Cu}_{3} \mathrm{Ni}$ (light-grey script) and $\mathrm{Al}_{3} \mathrm{Ni}$ (dark-grey script). The alloy AlSi12CuNiMg shows micro-hardness of around $100 \mathrm{HV}_{0,2}$. The selected hypo- eutectic alloy AlSi12CuNiMg shows tensile strength of around $280 \mathrm{MPa}$ and microhardness of around $100 \mathrm{HV}_{0,2}$. The microstructure is shown in Fig. 1.

The cladding material was $\mathrm{TiC}$ powder with a purity of $99,5 \%$. The diameter of $\mathrm{TiC}$ powder particles was between 4 and $8 \mu \mathrm{m}$. The powder was obtained from Global Tungsten \& Powder Corp., Towanda, USA. Dimensions of aluminium specimens prepared for laser cladding were $65 \times 20 \times 2,5 \mathrm{~mm}^{3}$. The specimen surface was grinded by emery paper 800 prior applying $\mathrm{TiC}$ cladding powder (TiC, $100 \mathrm{wt} . \%$ ) to the surface in order to eliminate the existence of thick oxides. A thin layer of pre-paste TiC powder (with approximate thickness of 0,15 $\mathrm{mm}$ ) was applied on the substrate surface by air gun. For better adhesion of $\mathrm{TiC}$ powder to the substrate surface, TiC powder was mixed with alcohol to form a sort of a wet paste.

\subsection{Laser surface cladding}

An unconventional approach using pulsed Nd:YAG laser which is typically used for welding was chosen to investigate the suitability of this technique for the surface cladding. Procedures using pulsed Nd:YAG laser could act as a cost-effective tool of advanced surface engineering or when effective repair procedure of damaged surface during its exploitation is needed, or both. The laser surface cladding was performed on specimens by means of OR Laser, type: ECO BU80 $\mathrm{Nd}$ :YAG laser with a maximum mean power of $80 \mathrm{~W}$ and top hat mode structure, using the following experimental parameters:

$$
\begin{array}{lll}
\text { - } & \text { Average pulse power: } & P_{\mathrm{a}}=46,5 \mathrm{~W} \\
\text { - } & \text { Wavelength: } & v=1064 \mathrm{~nm}, \\
\text { - } & \text { Frequency of pulse: } & f=7 \mathrm{~Hz}, \\
\text { - } & \text { Pulse duration: } & t_{\mathrm{p}}=8 \mathrm{~ms}, \\
\text { - } & \text { Maximum pulse power: } & P_{\mathrm{p}}=0,83 \mathrm{~kW} \\
\text { - } & \text { Pulse energy: } & E_{\mathrm{p}}=P_{\mathrm{p}} \cdot t_{\mathrm{p}}=6,64 \mathrm{~J}
\end{array}
$$

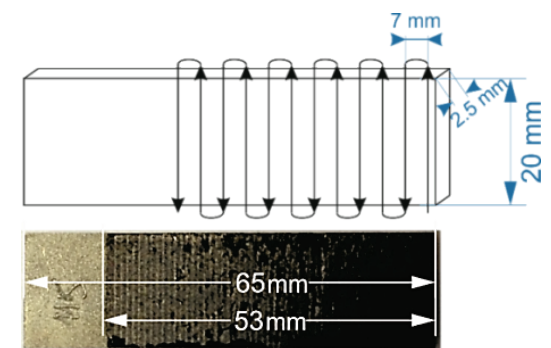

Figure 1 Laser beam movement across the specimen surface

In our experiment we were changing laser beam travelling speed and defocus - beam diameter on the specimen surface. Laser beam changed its movement at a distance of $0,7 \mathrm{~mm}$, as it is represented in Fig. 1. Laser beam changed the direction of movement outside the specimen. Argon protective gas of the 99,995\% purity and flow rate of $5 \mathrm{l} / \mathrm{min}$ was used during the whole process to minimize surface oxidation.

The following laser beam parameters were used:

- Beam travel speed: $v_{\mathrm{b}}=100 ; 150 \mathrm{~mm} / \mathrm{min}$

- Beam diameter on the specimen surface: $D_{\mathrm{b}}=0,82$; 1,$0 ; 1,18 \mathrm{~mm}$ 
- Laser path overlapping: $O_{\mathrm{p}}=\frac{0,7}{D_{\mathrm{b}}} \cdot 100 \%=85 ; 70$; $59 \%$

Overlapping factor $O_{\mathrm{f}}$ between laser pulses is defined in Fig. 2 and in Eq. (1) $[17,18]$, and results are shown in Tab. 1 .

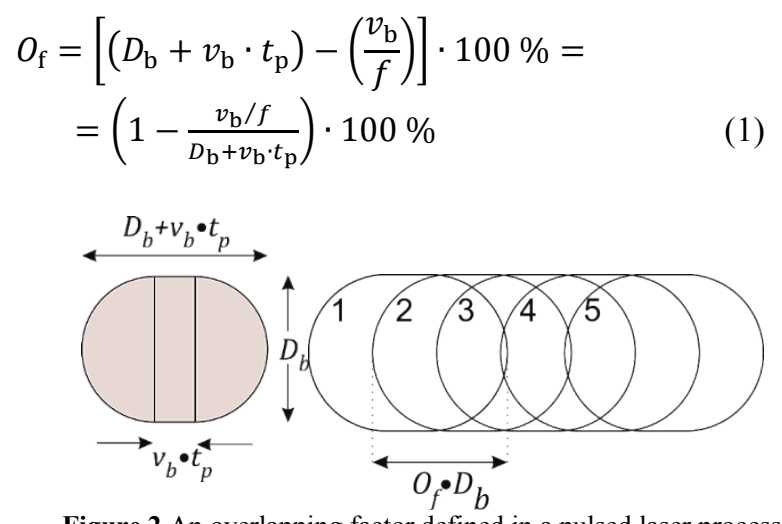

Figure 2 An overlapping factor defined in a pulsed laser process

For this study, laser peak power was set to be $P_{\mathrm{P}}=$ $0,83 \mathrm{~kW}$. Combination of pulse duration and pulse frequency was chosen in such a way that average power did not reach the limit of Nd:YAG laser system used.

Due to pulse nature of beam, energy density $(E D)$ and effective energy density $(E E D)$ were also calculated to find out the energy input per pulse and total energy input during laser processing $[17,18]$ :

$$
\begin{aligned}
& E D=\frac{E_{P}}{A} \quad\left(\mathrm{~J} / \mathrm{mm}^{2}\right) \\
& E E D=\frac{E_{\mathrm{P}} \cdot F}{A} \quad\left(\mathrm{~J} / \mathrm{mm}^{2}\right)
\end{aligned}
$$

where $A\left(\mathrm{~mm}^{2}\right)$ is area of laser spot on specimen, $F$ is the cumulative overlapping index defined as:

$F=1+n \cdot\left(1-(n+1) \cdot v_{\mathrm{b}} /\left(2 \cdot f \cdot D_{\mathrm{b}}\right)\right)$

$n=\frac{D_{\mathrm{b}} \cdot f}{v_{\mathrm{b}}}$

The results of the calculated effective energy density at the surface of cladding powder are presented in Tab. 1.

Table 1 Overlapping factor $O_{\mathrm{f}}(\%)$ between laser pulses and the calculated effective energy density $E E D\left(\mathrm{~J} / \mathrm{mm}^{2}\right)$ at the specimen surface

\begin{tabular}{|c|c|c|c|c|}
\hline \multirow{3}{*}{$\begin{array}{c}\text { Beam diameter } \\
(\mathrm{mm})\end{array}$} & \multicolumn{3}{|c|}{ Laser beam travel speed (mm/min) } \\
\cline { 2 - 5 } & \multicolumn{2}{|c|}{100} & \multicolumn{2}{c|}{150} \\
\cline { 2 - 5 } & $O_{\mathrm{f}}(\%)$ & $\begin{array}{c}E E D \\
\left(\mathrm{~J} / \mathrm{mm}^{2}\right)\end{array}$ & $O_{\mathrm{f}}(\%)$ & $\begin{array}{c}E E D \\
\left(\mathrm{~J} / \mathrm{mm}^{2}\right)\end{array}$ \\
\hline 0,82 & 71 & 28 & $/$ & $/$ \\
\hline 1,0 & 77 & 22 & 65 & 16 \\
\hline 1,18 & 80 & 18 & $/$ & $/$ \\
\hline
\end{tabular}

\subsection{Metallography}

For the metallographic characterization the specimens were ground and polished according to standard metallographic procedures. The top-view specimens and the cross-sections of the laser cladded samples were prepared. In order to reveal the microstructure the samples were chemically etched using an aqueous solution of $1 \mathrm{ml} \mathrm{HF}+2 \mathrm{ml} \mathrm{HCl}+3 \mathrm{ml} \mathrm{HNO}_{3}+94 \mathrm{ml}$ $\mathrm{H}_{2} \mathrm{O}$.

The measurements of the maximum depth of the laser-cladded zone, melted and the heat-affected zone were made using light microscopy. The metallographic examinations were performed using also field-emission scanning electron microscopy. In FE-SEM/EDS analyses the teardrop-shaped interaction volume depends on the element and the accelerating voltage. In this study, the FE-SEM/EDS analyses were performed at a $10 \mathrm{kV}$ accelerating voltage. Other factors that determine the detection limits of the EDS are: the counting time, the beam current, the line used to measure the element and the compositions of both the sample and the standards.

\subsection{Microhardness}

Microhardness was measured in accordance with the Vickers method, i.e. diamond pyramid hardness measurement, through the depth of the alloyed layer. Hardness was measured at a load of $200 \mathrm{~g}$ on metallographically polished, cross-section samples of laser cladded specimen.

In addition to the mentioned method the microhardness measurements were also performed separately in the matrix of the clad material at a load of 25 g.

\subsection{Surface roughness and waviness}

The surface roughness $(R a)$ and waviness $(W a)$ were measured using a profilemeter Surtronic 3+, TaylorHobson, with a sampling length of $8 \mathrm{~mm}$ and measurement speed of $0,5 \mathrm{~mm} / \mathrm{s}$. We have used Gaussian filter with a $3 \mathrm{~mm}$ sample range cut. The $R a$ and $W a$ values were calculated by averaging five measurement values obtained from five different locations of cladded surface.

\section{Results and discussion 3.1 Microstructure}

Laser surface cladding of the given aluminium alloy with $\mathrm{TiC}$ powder or particulates produced a characteristic microstructure, shown in Fig. 3. The specimen was coated with an average laser peak power density of 0,$759 ; 1,057$ and $1,572 \mathrm{~kW} / \mathrm{mm}^{2}$. In Fig. 3a we can notice three different zones: laser surface cladded zone, laser melted aluminium substrate, and base metal. There is an unexpressive heat affected zone between melted material and base metal. Average thickness of laser cladded layer is around $108 \mu \mathrm{m}$, in the range between 22 and $250 \mu \mathrm{m}$. Average thickness of melted aluminium beneath laser cladded layer is around $135 \mu \mathrm{m}$, in the range between 50 and $220 \mu \mathrm{m}$. In Fig. $3 \mathrm{~b}$ we can observe porosity between laser cladded layer and substrate. Porosity is present also in the cladded layer, and it affects surface roughness too. Uenishi et al. [20] claimed that to obtain TiC clad layer well bound with Al base metal, laser power should be supplied enough to melt not only cladding powders but $\mathrm{Al}$ base metal superficially. At $\mathrm{TiC}$ laser cladding with 
continuous laser almost no porosity was observed [13, 15, $19]$.
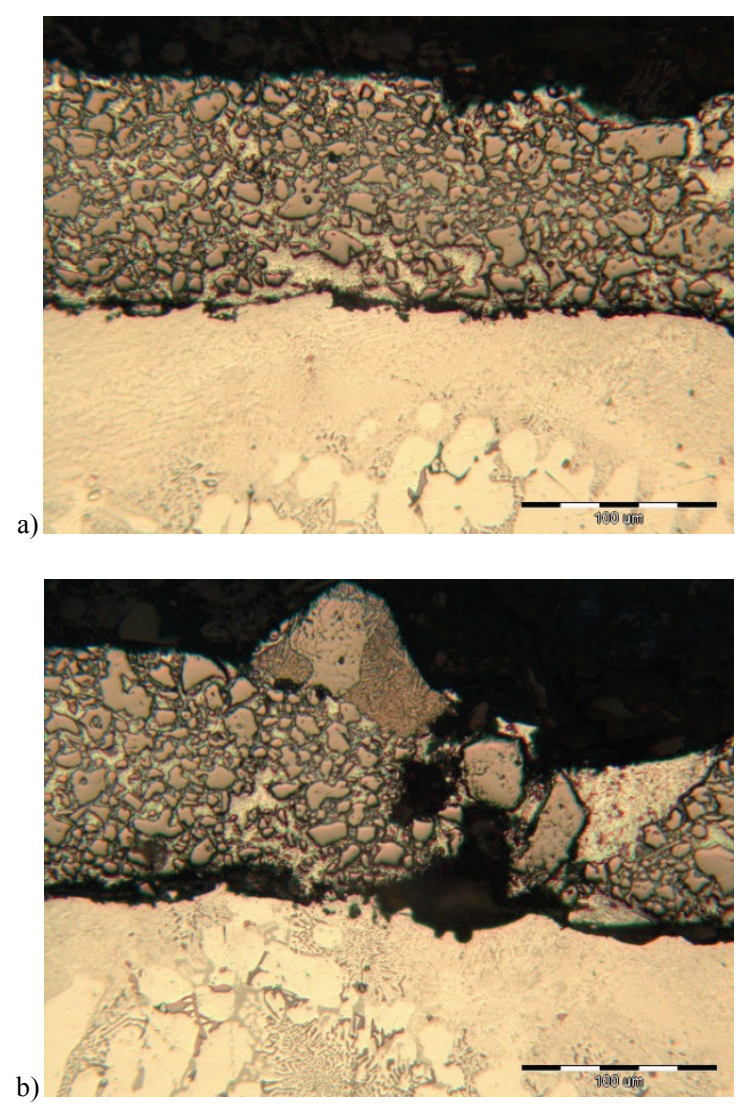

Figure 3 Microstructure of TiC laser surface cladding, etched

In Tab. 2 is presented correlation between $D_{\mathrm{b}}, O_{\mathrm{f}}$, $E E D$, and dimensions of laser cladded surface. We can notice a little decrease of cladded layer dimensions with decrease of $E E D$. But the decrease in dimension is not in correlation with decrease in EED. Farnia et al. [17] showed that the effects of pulse duration and overlapping factor are different at low and high values. When pulse duration increases, the interaction time between laser beam and the material increases which results in a decrease in $E E D$.

Table 2 Dimensions of TiC modified surface at laser beam travel speed

\begin{tabular}{|c|c|c|c|c|}
\hline $\begin{array}{c}D_{b} \\
(\mathrm{~mm})\end{array}$ & $\begin{array}{c}O_{f} \\
(\%)\end{array}$ & $\begin{array}{c}E E D \\
\left(\mathrm{~J} / \mathrm{mm}^{2}\right)\end{array}$ & $\begin{array}{c}\text { Cladded zone } \\
(\mu \mathrm{m})\end{array}$ & $\begin{array}{c}\text { Melted zone } \\
(\mu \mathrm{m})\end{array}$ \\
\hline 0,82 & 71 & 28 & $101 \pm 20$ & $150 \pm 40$ \\
\hline 1,0 & 77 & 22 & $139 \pm 75$ & $137 \pm 30$ \\
\hline 1,18 & 80 & 18 & $99 \pm 45$ & $55 \pm 50$ \\
\hline
\end{tabular}

The region under the resulting coating is known as the laser melted zone ( $L M Z)$. Detailed measurements of the thickness of the laser melted zone revealed that the thickness increased a little with increasing energy input. The laser melted zone illustrates a cellular dendritic microstructure, typical of cast aluminium alloys. The same structure was found also by Ravnikar et al. [6] at continuous laser cladding of aluminium alloy.

The whole modified layer depth remains around 240 $\pm 50 \mu \mathrm{m}$ in the case of selected laser cladding parameters. In the transition between $L M Z$ and base material there is heat affected zone $(H A Z)$. The region is hard to distinguish, because changes on microstructure are in very small scale and were estimated between $4 \mu \mathrm{m}$ and $25 \mu \mathrm{m}$. Sahoo et al [18] discovered that increase in overlapping factor and laser peak power increase the laser processed composite layer depth and width.
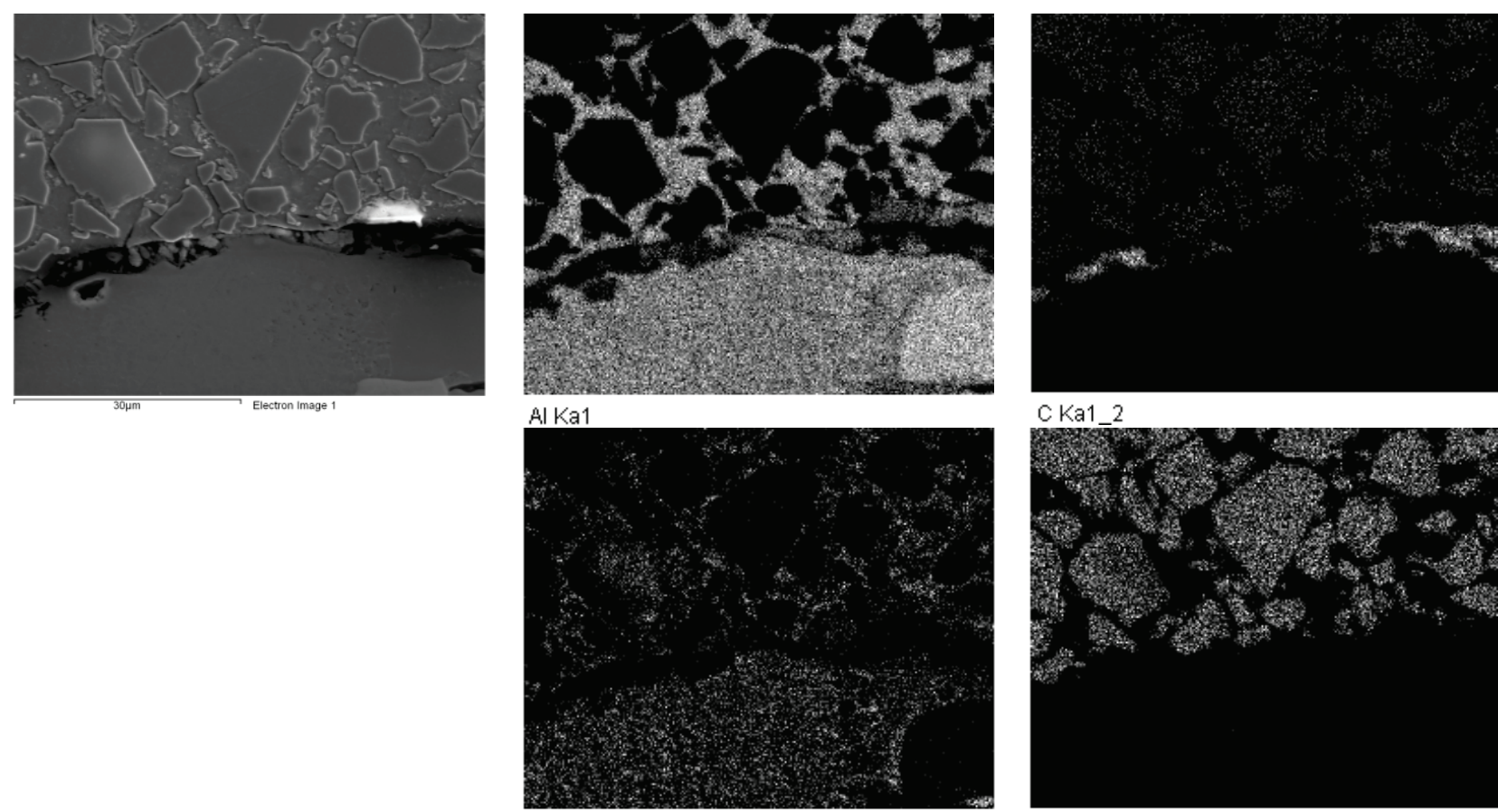

Si Ka1

Ti Ka1

Figure4 SE image of TiC cladded surface layer. The corresponding X-Ray elemental mappings show the distribution of Al, Si, Ti and C

In Fig. 4 the distribution of elements is shown in the laser cladded zone. The results of a microchemical surface analysis are presented for $\mathrm{Al}, \mathrm{Si}$, Ti and C. As anticipated, aluminium and silicium were found as a part 
of the substrate as well as a part of the matrix material around facets in the laser cladded zone. Carbon and titanium were found to occupy position in the facets which indicate the presence of TiC. Du et al. [21] have according to their results concluded that the rectangular facets are related to the presence of $\mathrm{TiB}_{2}$ and the spherical ones with TiC. With our research we cannot confirm Du's conclusions regarding shape of $\mathrm{TiC}$ facets.

Qualitative analysis of the cladded surface with $\mathrm{TiC}$ powder was performed in designated measuring positions, illustrated in Fig. 5.

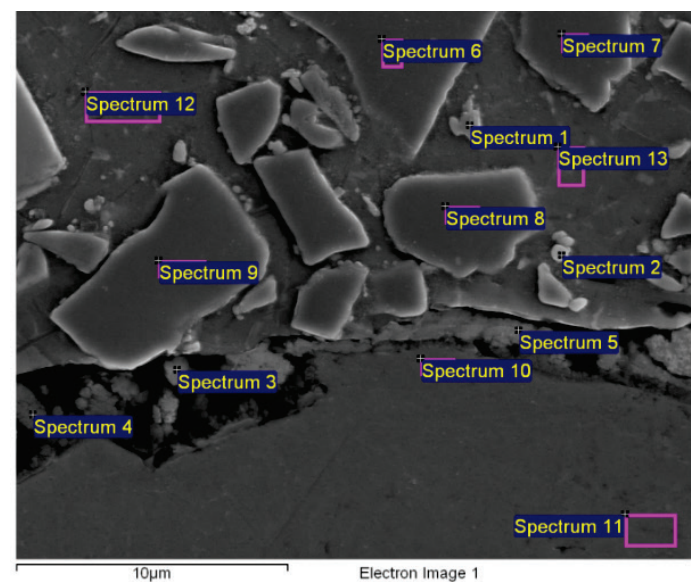

Figure 5 Selected and measured regions using EDS analyses of TiC cladded surface

Using EDS analysis, seven elements were identified in the coating: $\mathrm{Al}, \mathrm{Ti}, \mathrm{C}, \mathrm{O}, \mathrm{Si}, \mathrm{Mg}$ and $\mathrm{Cu}$. Tab. 3 shows individual measuring positions in the coating with various elements, on the basis of which the presence of different phases may be inferred. The presence of $\mathrm{C}$ and $\mathrm{Ti}$ in bigger facets designated with spectrum $6,7,8$ and 9 indicated the existence of TiC.

Table 3 EDS analysis from Fig. 5 (results are given in wt.\%)

\begin{tabular}{|c|c|c|c|c|c|c|c|}
\hline Spectrum & $\mathrm{C}$ & $\mathrm{O}$ & $\mathrm{Mg}$ & $\mathrm{Al}$ & $\mathrm{Si}$ & $\mathrm{Ti}$ & $\mathrm{Cu}$ \\
\hline 1 & 21,94 & $/$ & $/$ & 16,54 & 2,65 & 57,16 & 1,70 \\
\hline 2 & 20,47 & $/$ & $/$ & 20,35 & 5,61 & 52,63 & 0,95 \\
\hline 3 & 15,72 & 25,86 & 2,42 & 53,23 & 1,69 & 1,09 & $/$ \\
\hline 4 & 9,89 & 40,30 & 4,48 & 44,26 & 1,08 & $/$ & $/$ \\
\hline 5 & 5,15 & 13,71 & 0,67 & 78,19 & 1,51 & 0,77 & $/$ \\
\hline 6 & 21,74 & $/$ & $/$ & 0,55 & 0,27 & 77,44 & $/$ \\
\hline 7 & 21,06 & $/$ & $/$ & 0,64 & $/$ & 78,30 & $/$ \\
\hline 8 & 20,50 & $/$ & $/$ & 0,66 & $/$ & 78,84 & $/$ \\
\hline 9 & 21,30 & $/$ & $/$ & 0,70 & $/$ & 78,00 & $/$ \\
\hline 10 & 2,87 & 2,91 & 5,10 & 71,59 & 16,09 & $/$ & 1,45 \\
\hline 11 & 2,49 & 0,79 & 5,28 & 77,60 & 13,85 & $/$ & $/$ \\
\hline 12 & 3,83 & 1,17 & $/$ & 84,39 & 8,03 & 1,50 & 1,08 \\
\hline 13 & 2,30 & 0,81 & $/$ & 78,29 & 16,38 & 1,52 & 0,70 \\
\hline
\end{tabular}

In smaller facets designated with spectrum 1 and 2 we can find also $\mathrm{Al}$ and some $\mathrm{Si}$ which shows on dissolution of $\mathrm{TiC}$ in aluminium matrix and formation of new phases like $\mathrm{Al}_{4} \mathrm{C}_{3}$ and $\mathrm{Al}_{3} \mathrm{Ti}[5,6,19]$. In a similar TiC cladded layer Jianing et al. [11] have found also $\mathrm{Ti}_{3} \mathrm{Al}$ and TiAl phases. The reinforcement of the laser cladding layer was mainly contributed to the action of $\mathrm{Ti}_{3} \mathrm{Al} / \mathrm{Al}_{3} \mathrm{Ti}+\mathrm{TiC}$ hard phases [11]. Dubourg et al. [15] have stated that $\mathrm{Al}_{4} \mathrm{C}_{3}$ carbide precipitation bust is avoided due to the brittleness of $\mathrm{Al}_{4} \mathrm{C}_{3}$ phase surrounding the TiC reinforcement. Spectrum 12 and 13 indicated melted substrate material which due to the capillary effect during the cladding process fills the pores between ceramic components.

A sufficiently high energy density causes the dissolution of $\mathrm{TiC}$ in this aluminium substrate. Between laser cladded zone and aluminium substrate in spectrum 3,4 and 5 carbon and aluminium were found as well as oxygen and small amounts of titanium and silicon. This could affect the occurrence of aluminium oxycarbide.

\subsection{Microhardness}

Average microhardness measurements were performed with a $200 \mathrm{~g}$ load in the middle of a cladded layer, and in the middle of the melted layer. The average microhardness of $\mathrm{TiC}$ laser cladded layer is about $850 \pm$ $570 \mathrm{HV}_{0,2}$. Average microhardness of $\mathrm{TiC}$ cladded layer is independent of selected laser processing parameters. Sahoo et al. [18] found out that average microhardness value of the $\mathrm{TiC}$ composite layer is considerably high for using lower peak power but uniformity in the hardness value is less. At higher peak power relatively low but uniform hardness value was obtained [18]. In addition to this Ochonogor et al. [13] have discovered that there is no correlation between hardness and abrasive wear due to differences in composition. Microhardness in the melted layer is much lower than in the cladded layer. It is around $164 \pm 20 \mathrm{HV}_{0,2}$ which is higher than the microhardness of the base substrate material of $100 \mathrm{HV}_{0,2}$.

Because of relatively homogeneous structure in base substrate material and in melted layer standard deviation of microhardness values is low. Quite the opposite is standard deviation of microhardness measurements in TiC laser cladded layer. Due to mixture of hard TiC facets surrounded by soft aluminium matrix is standard deviation of hardness measurements reasonably high. The cladded layer contains about $62 \%$ of carbides and $29 \%$ of aluminium as metallic bound, as it is shown in crosssection of cladded layer in Fig. 6.

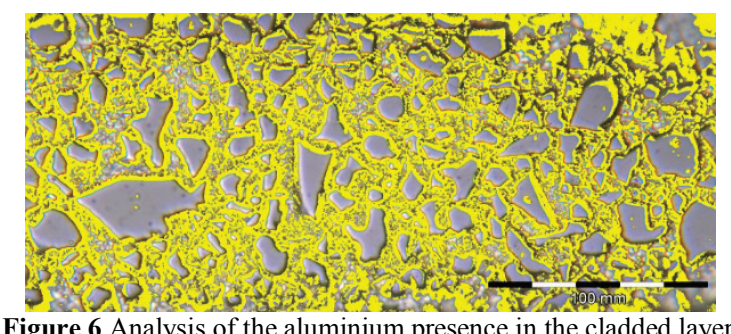

For better microstructure evaluation in $\mathrm{TiC}$ laser cladded layer, microhardness measurements with a load of $25 \mathrm{~g}$ were performed at specific structure constituents. From the results presented in Fig. 7 we can establish that there is a great variety of microhardness values. TiC facets reach microhardness values between 3000 and $5000 \mathrm{HV}_{0,025}$. The aluminium matrix around $\mathrm{TiC}$ facets has microhardness around $250 \mathrm{HV}_{0,025}$, and microhardness of some small facets in this matrix is between 400 and $1400 \mathrm{HV}_{0,025}$. 


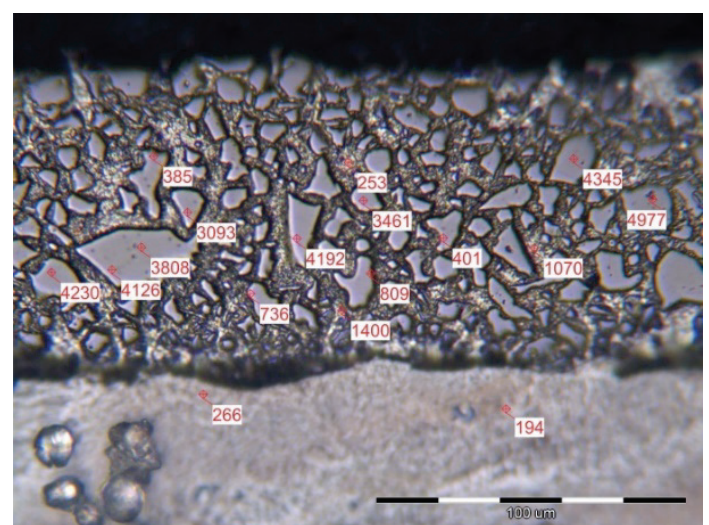

Figure 7 Microhardness $\left(\mathrm{HV}_{0,025}\right)$ of the structure in the $\mathrm{TiC}$ laser cladded layer

\subsection{Surface roughness and waviness}

In this study beam diameter, laser beam travel speed and beam overlapping factor are chosen as laser parameters to be optimized for reducing average surface roughness $(R a)$ at laser surface cladding of $\mathrm{TiC}$ powder over aluminium alloy. The surface roughness values $(R a)$ obtained in laser cladding of aluminium alloy according to laser beam diameter, laser beam travel speed and laser beam overlapping factor are shown in Tab. 4 .

Table 4 Surface roughness $R a$ of laser cladded surface with $\mathrm{TiC}$ powder

\begin{tabular}{|c|c|c|c|c|}
\hline $\begin{array}{c}D_{\mathrm{b}} \\
(\mathrm{mm})\end{array}$ & $\begin{array}{c}v_{\mathrm{b}} \\
(\mathrm{mm} / \mathrm{min})\end{array}$ & $\begin{array}{c}O_{\mathrm{f}} \\
(\%)\end{array}$ & $\begin{array}{c}R a(\mu \mathrm{m}) \\
\| \text { to laser path }\end{array}$ & $\begin{array}{c}R a(\mu \mathrm{m}) \\
\perp \text { to laser path }\end{array}$ \\
\hline 0,82 & 100 & 71 & 9,32 & 5,42 \\
\hline 1,0 & 100 & 77 & 10,30 & 11,70 \\
\hline 1,18 & 100 & 80 & 11,60 & 13,50 \\
\hline 1,0 & 150 & 65 & 15,20 & 11,70 \\
\hline
\end{tabular}

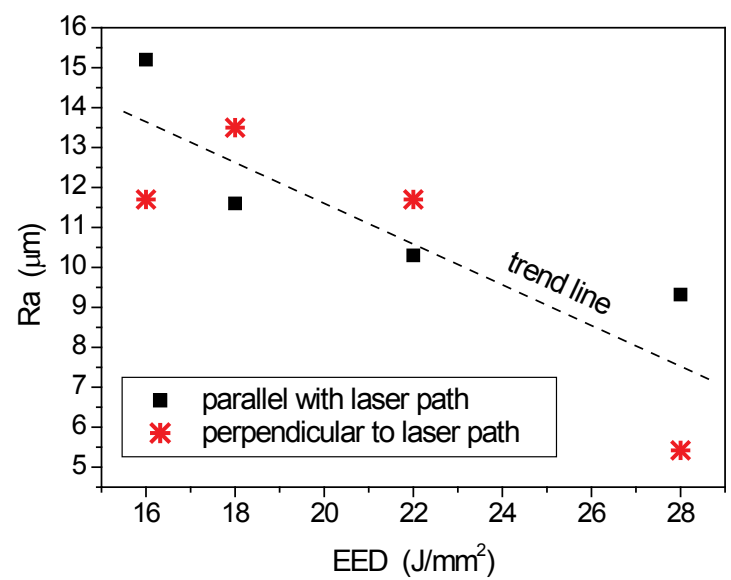

Figure 8 Surface roughness $R a$ of laser cladded surface

As seen from Tab. 4, the $R a$ values show irregular tendency. Laser beam travel speed increase influences the increase of the $R a$. In other words, when we decrease beam overlapping factor, the $R a$ values increase. But when we observe another combination of laser parameters, we can find out that increasing laser beam diameter influences the increase of $R a$. In other words, when we increase beam overlapping factor, the $R a$ values increase. So in Tab. 4 we cannot find any correlation between laser beam parameters and $R a$ values of cladded surface. But when we compare $R a$ values with effective energy density (EED), we find good correlation (Fig. 8).
When we increase $E E D$ from 16 to $28 \mathrm{~J} / \mathrm{mm}^{2}$, the surface roughness $R a$ decreases in both directions parallel with and perpendicular to laser paths. The highest $R a$ value has been observed as $15,20 \mu \mathrm{m}$ at $E E D=16 \mathrm{~J} / \mathrm{mm}^{2}$, and the lowest as $5,42 \mu \mathrm{m}$ at $E E D=28 \mathrm{~J} / \mathrm{mm}^{2}$. So we can state, the dominant factor affecting the $R a$ is $E E D$. Very similar statement was expressed by Sahoo et al. [22] who discovered that overall energy input causes better mixing of the preplaced $\mathrm{TiC}$ powder with $\mathrm{Al}$ substrate material.

Waviness $(\mathrm{Wa})$ is the average of the peak heights of the surface after the roughness values used to calculate $R a$ have been removed, and therefore represents the larger scale rippled surface texture.

In the case of laser cladding of $\mathrm{TiC}$ powder a decrease in the surface roughness is clearly observed when increasing $E E D$. The waviness however does not share the trend of the $R a$ roughness with changing EED.

The surface waviness values $(\mathrm{Wa})$ obtained in laser cladding of aluminium alloy according to laser beam diameter, laser beam travel speed and laser beam overlapping factor are shown in Tab. 5. The maximum surface waviness is less than $63 \mu \mathrm{m}$ and minimum $W a=15$ $\mu \mathrm{m}$. It is evident that with increasing $E E D$, the surface waviness tends to increase (Fig. 9).

Table 5 Surface waviness $W a$ of laser cladded surface

\begin{tabular}{|c|c|c|c|c|}
\hline $\begin{array}{c}D_{\mathrm{b}} \\
(\mathrm{mm})\end{array}$ & $\begin{array}{c}v_{\mathrm{b}} \\
(\mathrm{mm} / \mathrm{min})\end{array}$ & $\begin{array}{c}O_{\mathrm{f}} \\
(\%)\end{array}$ & $\begin{array}{c}W a(\mu \mathrm{m}) \\
\| \text { to laser path }\end{array}$ & $\begin{array}{c}W a(\mu \mathrm{m}) \\
\perp \text { to laser path }\end{array}$ \\
\hline 0,82 & 100 & 71 & 46,8 & 49,14 \\
\hline 1,0 & 100 & 77 & 38,1 & 44,2 \\
\hline 1,18 & 100 & 80 & 62,6 & 46,9 \\
\hline 1,0 & 150 & 65 & 38,1 & 15,1 \\
\hline
\end{tabular}

The cladded surface is characterized by waviness $W a$ $=40 \pm 20 \mu \mathrm{m}$ and roughness $R a=10 \pm 6 \mu \mathrm{m}$. $W a$ is gradually increasing when $E E D$ is increasing, and on the contrary $R a$ is evidently decreasing when increasing $E E D$.

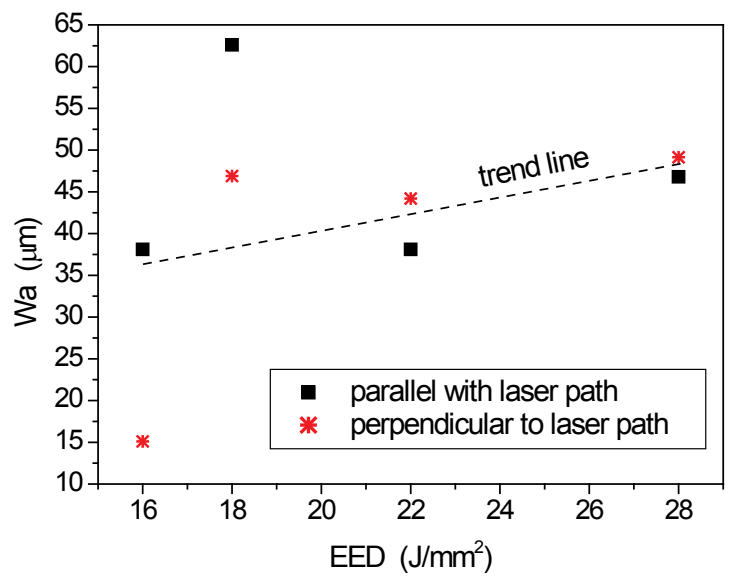

Figure 9 Surface waviness $\mathrm{Wa}$ of laser cladded surface

\section{Conclusions}

A hard layer of $\mathrm{TiC}$ was deposited on aluminium AlSi12CuNiMg alloy substrate after laser irradiation over TiC preplaced aluminium surface using Nd:YAG laser. In this research we have used different laser processing parameters. From the experimental analysis the following conclusions can be drawn: 
- Microstructure of cladded layer is composed of TiC facets surrounded by aluminium matrix. The adhesion between laser cladded layer and melted substrate beneath it is weak due to presence of porosity.

- The average microhardness of cladded layer is $850 \pm$ $570 \mathrm{HV}_{0,2}$. TiC facets reach microhardness values between 3000 and $5000 \mathrm{HV}_{0.025}$.

- Pulse laser parameter i.e. effective energy density $(E E D)$ defined with pulse energy, laser spot area and cumulative overlapping index has great influence on the formation of $\mathrm{TiC}$ cladded layer.

- Surface roughness $(R a)$ is decreasing with increasing effective energy density $(E E D)$ of laser beam at the surface.

- Surface waviness $(W a)$ is increasing when effective energy density $(E E D)$ of laser beam at the surface is increasing.

- Proper combination of peak power, overlapping factor and pulse duration is required to create a defect-free and uniform coating using pulse laser.

\section{References}

[1] Major, B. Laser processing for surface modification by remelting and alloying of metallic systems. Pauleau, Y. (ed.) Materials surface processing by directed energy techniques. Elsevier, Amsterdam, (2006), pp. 241-274. DOI: 10.1016/b978-008044496-3/50008-3

[2] Dua, B.; Paital, S. R.; Dahotre, N. B. Synthesis of $\mathrm{TiB}_{2}-$ $\mathrm{TiC} / \mathrm{Fe}$ nano-composite coating by laser surface engineering. // Optics \& Laser Technology. 45, (2013), pp. 647-653. DOI: 10.1016/j.optlastec.2012.05.017

[3] Masanta, M.; Shariff, S. M.; Choudhury, A. R. A comparative study of the tribological performances of laser clad $\mathrm{TiB}_{2}-\mathrm{TiC}-\mathrm{Al}_{2} \mathrm{O}_{3}$ composite coatings on AISI 1020 and AISI 304 substrates. // Wear. 271, (2011), pp. 1124-1133. DOI: 10.1016/j.wear.2011.05.009

[4] Masanta, M.; Shariff, S. M.; Choudhury, A. R. Evaluation of modulus of elasticity, nano-hardness and fracture toughness of $\mathrm{TiB}_{2}-\mathrm{TiC}-\mathrm{Al}_{2} \mathrm{O}_{3}$ composite coating developed by SHS and laser cladding. // Materials Science and Engineering. A 528, (2011), pp. 5327-5335. DOI: 10.1016/j.msea.2011.03.057

[5] Ravnikar, D.; Dahotre, N. B.; Grum, J. Laser coating of aluminum alloy EN AW 6082-T651 with $\mathrm{TiB}_{2}$ and TiC:Microstructure and mechanical properties. // Applied Surface Science. 282, (2013), pp. 914-922. DOI: 10.1016/j.apsusc.2013.06.089

[6] Ravnikar, D.; Mrvar, P.; Medved, J.; Grum, J. Microstructural analysis of laser coated ceramic components $\mathrm{TiB}_{2}$ and $\mathrm{TiC}$ on aluminium alloy EN AW6082-T651. // Strojniški vestnik - Journal of Mechanical Engineering. 59, 5(2013), pp. 281-290. DOI: 10.5545/svjme.2012.904

[7] Powell. J.; Henry, P. S.; Steen, W. M. Laser cladding with pre-placed powder: analysis of thermal cycling and dilution effects. // Surface Engineering. 4, 2(1988), pp. 141-149. DOI: 10.1179/sur.1988.4.2.141

[8] Deng, Ch.; Zhang, Y. P.; Gao, J. Ch. Numerical simulation of temperature field for bioceramic coating cladded by laser. // Journal of Material Science and Engineering. 21 (2003), pp. 503-506.

[9] Lietchi, T.; Blank, E. Surface Modification Technologies, Sudarshan, T. S. (Ed.), vol. VIII, TMS Publication, 1995, pp. 421-427.

[10] Lei, Y.; Sun, R.; Lei, J.; Tang, Y.; Niu, W. A new theoretical model for high power laser clad $\mathrm{TiC} / \mathrm{NiCrBSiC}$ composite coatings on $\mathrm{Ti}_{6} \mathrm{Al}_{4} \mathrm{~V}$ alloys. // Optics and Lasers in Engineering. 48, (2010), pp. 899-905. DOI: 10.1016/j.optlaseng.2010.03.016

[11] Jianing, L.; Chuanzhong, C.; Lei, Z. Microstructure characteristics of $\mathrm{Ti}_{3} \mathrm{Al} / \mathrm{TiC}$ ceramic layer deposited by laser cladding. // Int. Journal of Refractory Metals and Hard Materials. 29, (2011), pp. 49-53. DOl: 10.1016/j.jijmhm.2010.07.001

[12] Kadolkar, P. B.; Watkins, T. R.; De Hosson, J. Th. M.; Kooi, B. J.; Dahotre, N. B. State of residual stress in laserdeposited ceramic composite coatings on aluminum alloys. // Acta Materialia. 55, (2007), pp. 1203-1214. DOl: 10.1016/j.actamat.2006.07.049

[13] Ochonogor, O. F.; Meacock, C.; Abdulwahab, M.; Pityana, S.; Popoola, A. P. I. Effects of Ti and TiC ceramic powder on laser-cladded $\mathrm{Ti}-6 \mathrm{Al}-4 \mathrm{~V}$ in situ intermetallic composite. // Applied Surface Science. 263, (2012), pp. 591-596. DOI: 10.1016/j.apsusc.2012.09.114

[14] Duraiselvam, M.; Galun, R.; Wesling, V.; Mordike, B. L.; Reiter, R.; Oligmuller, J.; Buvanashekaran, G. Cavitation erosion resistance of $\mathrm{Ti}_{6} \mathrm{Al}_{4} \mathrm{~V}$ laser alloyed with TiCreinforced dual phase intermetallic matrix composites. // Materials Science and Engineering. A 454-455, (2007), pp. 63-68. DOI: 10.1016/j.msea.2006.11.002

[15] Dubourg, L.; Ursescu, D.; Hlawka, F.; Cornet, A. Laser cladding of MMC coatings on aluminium substrate: influence of composition and microstructure on mechanical properties. // Wear. 258, (2005), pp. 1745-1754. DOl: 10.1016/j.wear.2004.12.010

[16] Ion, J. C. Laser processing of engineering materials. Elsevier Amsterdam: Elsevier publication; 2005, pp. 296321.

[17] Farnia, A.; Ghaini, F. M.; Sabbaghzadeh, J. Effects of pulse duration and overlapping factor on melting ratio in preplaced pulsed Nd:YAG laser cladding. // Optics and Lasers in Engineering. 51, (2013), pp. 69-76. DOl: 10.1016/j.optlaseng.2012.07.015

[18] Sahoo, C. K.; Masanta, M. Effect of pulse laser parameters on $\mathrm{TiC}$ reinforced AISI 304 stainless steel composite coating by laser surface engineering process. // Optics and Lasers in Engineering. 67, (2015), pp. 36-48. DOI: 10.1016/j.optlaseng.2014.10.010

[19] Katipelli, L. R.; Agarwal, A.; Dahotre, N. B. Laser surface engineered $\mathrm{TiC}$ coating on $6061 \mathrm{Al}$ alloy - microstructure and wear. // Applied Surface Science. 153, 2-3(2000), pp. 65-78. DOI: 10.1016/s0169-4332(99)00368-2

[20] Uenishi, K.; Kobayashi, K. F. Formation of surface layer based on Al3Ti on aluminum by laser cladding and its compatibility with ceramics. // Intermetallics. 7, (1999), pp. 553-559. DOI: 10.1016/S0966-9795(98)00071-5

[21] Du, B.; Zou, Z.; Wang, X., Li, Q. In situ synthesis of TiCTiB2 reinforced $\mathrm{FeCrSiB}$ composite coating by laser cladding. // Surface Review and Letters. 14, (2007), pp. 315-319. DOI: 10.1142/S0218625X07009414

[22] Sahoo, C. K.; Sahu, J. K.; Masanta, M. Effect of pulsed $\mathrm{Nd}$ :YAG laser parameters in preplaced $\mathrm{TiC}$ coating on aluminium substrate. $/ / 5^{\text {th }}$ Int. \& $26^{\text {th }}$ all India Manufacturing Technology, Design and Research Conference (AIMTDR 2014) / Guwahati, Assam, India, 2014, pp. 255:1-6. 


\section{Authors' addresses}

\section{Janez Sušnik}

Faculty of Mechanical Engineering

University of Ljubljana

Aškerčeva 6,1000 Ljubljana, Slovenia

E-mail: janez.susnik@fs.uni-lj.si

\section{Janez Grum, Professor}

Faculty of Mechanical Engineering

University of Ljubljana

Aškerčeva 6,1000 Ljubljana, Slovenia

E-mail: janez.grum@fs.uni-lj.si

Roman Šturm, Assoc. Professor

Faculty of Mechanical Engineering

University of Ljubljana

Aškerčeva 6, 1000 Ljubljana, Slovenia

E-mail: roman.sturm@fss.uni-lj.si 